\title{
POTENTIAL OF MACAUBA EPICARP (Acrocomia aculeata (Jacq.) Lodd. ex Martius) FOR BRIQUETTES PRODUCTION
}

\author{
Vinícius Lima Teixeira $^{1 *}$, Angélica de Cássia Oliveira Carneiro ${ }^{1}$, Anderson Barbosa Evaristo ${ }^{2}$, Bruno de Freitas \\ Homem de Faria ${ }^{1}$, Danilo Barros Donato ${ }^{1}$, Mateus Alves de Magalhães ${ }^{1}$ \\ ${ }^{1}$ Federal University of Viçosa, Department of Forestry, Viçosa, Minas Gerais, Brazil - vinicius.limateixeira@yahoo.com*; \\ cassiacarneiro1@gmail.com; bruno.homemfaria@gmail.com; danilobdonato@gmail.com; mateusmagalhaes91@gmail.com \\ ${ }^{2}$ Federal University of Jequitinhonha and Mucuri Valleys (UFVJM), Institute of Agrarian Sciences (ICA), Diamantina, Minas Gerais, Brazil \\ - evaristo.ab@gmail.com
}

Received for publication: 12/01/2018 - Accepted for publication: 15/05/2018

\begin{abstract}
Briquetting is a form to aggregate value in the biomass production chain, to re-use sustainably waste and to provide high-quality solid biofuels, as well as to enable the development of the energy market. The aim of this study was to evaluate the potential of the production of briquettes from epicarp waste of macauba fruit and verify the influence of different temperatures and compaction pressures on the chemical, physical, and mechanical characteristics of the briquettes. The epicarp was reduced to particles and, then classified, dried, and characterized for their physical and chemical properties. The briquettes were produced by using compression pressures of 62,83 , and 103 bar and temperatures of 90 and $120{ }^{\circ} \mathrm{C}$. The effect of these factors upon the variables studied was verified through regression analysis. The increase of pressure and temperature contributed to greater mass loss of the briquettes. Apparent density and energy density increased due to temperature rise. High values of energy density were obtained, which demonstrates the potential of the macauba fruit epicarp to produce briquettes for generation of thermal energy.

Keywords: Bioenergy, biomass, briquetting.
\end{abstract}

\section{Resumo}

Potencial do epicarpo de macaúba (Acrocomia aculeata (Jacq.) Lodd. Ex Martius) para produção de briquetes. A briquetagem é uma forma de agregar valor à cadeia produtiva da biomassa, reutilizar resíduos de forma sustentável e disponibilizar biocombustíveis sólidos de alta qualidade, propiciando o desenvolvimento do mercado energético. O objetivo deste estudo foi avaliar o potencial da produção de briquetes a partir de resíduos do epicarpo do fruto da macaúba e verificar a influência de diferentes temperaturas e pressões de compactação sobre as características químicas, físicas e mecânicas dos briquetes. O epicarpo foi reduzido a partículas, que foram classificadas, secas e caracterizadas quanto às propriedades físicas e químicas. Os briquetes foram produzidos adotando-se as pressões de compactação de 62, 83 e 103 bar e temperaturas de 90 e $120^{\circ} \mathrm{C}$. O efeito desses fatores sobre as variáveis estudadas foi verificado através da análise de regressão. $\mathrm{O}$ acréscimo de pressão e temperatura contribuiu para uma maior perda de massa dos briquetes. A densidade aparente e a densidade energética tiveram elevação decorrente do aumento da temperatura. Foram obtidos elevados valores de densidade energética, demonstrando o potencial do epicarpo do fruto da macaúba para produção de briquetes visando a geração de energia térmica.

Palavras-chave: Bioenergia, biomassa, briquetagem.

\section{INTRODUCTION}

In 2016, there was an increase of $2.2 \%$ in the share of renewable resources in the Brazilian energy matrix, which accounts for $43.5 \%$ of the total. This was due to the fall in the domestic supply of oil and oil products and the expansion of hydroelectric generation. The main representative of the renewable sources was sugarcane biomass with $17.5 \%$, followed by hydroelectric power with $12.6 \%$. Firewood and charcoal, despite having a reduction, contributed $8 \%$ (EPE, 2017). Considering the need to replace fossil fuels and the diversification of the country's energy matrix, it is necessary that research focused on renewable energy sources be developed to supplement to water systems.

Therefore, biomass is highlighted as an important energy alternative, whether it be sourced from forestry, agricultural systems, or industrial waste (PROTÁSIO et al., 2011). The use of biomass residues for the production of solid fuels is a good option, as it is a way to offer products with greater added value, develop the production chain, and promote the best use of the raw material.

The biodiesel industry has a nominal capacity to produce about 7.4 million $\mathrm{m}^{3}$ of material, distributed in 58 production units that are present in all regions of the country (ANP, 2016). One of its characteristics is the 
high generation of residues in the form of bran and bark, among others, which need to have well defined destinations because they can subsidize or even make the production system more feasible.

This market identifies the macauba (Acrocomia aculeata (Jacq.) Lodd. Ex Martius) as a promising source of raw material due to its great productivity of fruits, seeds, and oil even in the first years of growth. In addition, they are perennial plants, which contribute to the generation of jobs and allows for workers to live in rural areas (FAVARO; MIRANDA, 2013). The macauba is found throughout South America and, in Brazil, is found in different ecosystems, including the Atlantic Forest and Cerrado biomes (MONTOYA et al., 2016). It is a palm tree that can reach more than $16 \mathrm{~m}$, in addition to presenting many thorns along the stem (EVARISTO et al., 2016).

Another great advantage is its ample potential of use. Its stem can be used as poles and posts in natura. The apical meristem can be used as food (palmito), the leaves as fodder, and the fruits can be used in several ways. For example, the mesocarp can be used in the manufacture of juices, ice cream, and animal feed. Mesocarp oil can also be used as, for example, cooking oil, soap, and, ultimately, biodiesel. The almonds can be consumed in natura, and its oil has use in the cosmetics and oleochemical industries (LORENZI; NEGRELLE, 2006). The epicarp and the endocarp can be used for producing good quality coal because they have high values of bulk density, calorific value, and fixed carbon. This coal presents these improved qualities with the exception of the ash content, which is higher in comparison to the coal produced with Eucalyptus wood (EVARISTO et al., 2016). According to Evaristo et al. (2016), the pulp constitutes the greater part of the fruit of the macauba, $38.5 \%$ in relation to the dry mass; the endocarp represents $32.0 \%$, followed by the epicarp with $22.2 \%$, and the almond has $7.3 \%$ of the total.

When macauba fruits are processed for the production of biodiesel, one of the valuable residues is the epicarp, which can be used in a cogeneration system for costs reduction and generating revenues for the production unit. An alternative to its use is briquettings, which consists of the application of pressure to a mass of particles, with or without the addition of binder and temperature (MARTINS et al., 2016), in order to obtain products with shape, size, and mechanical parameters suitable for transport and storage. Briquettes may be used as a complement or as a substitute for petroleum products, firewood, and gas. Also, they can be used in steam generation and thermoelectricity production, contributing to reduction of waste deposited incorrectly in the environment.

Many variables influence the properties of the briquettes and can be both properties of the raw material, such as moisture content, higher calorific value (HCV), and bulk density (BD), as well as variables of the compaction process, such as temperature, pressure, and use of binders. The higher calorific value can be defined as the amount of available energy that is released in the complete combustion of a unit of mass of the fuel (PROTÁSIO et al., 2011) and is an important indicator of the energy generation potential of a biomass.

Heating during compaction allows for the production of more stable and smaller products in comparison to those made with biomass of the same composition that are not heated (DIAS et al., 2012). In addition to the high temperatures, the lignin plasticizes and acts as a binder between the particles, in addition to forming a film that protects the briquette from moisture variations (FREITAS et al., 2016). The application of high compaction pressures in the biomass particles promotes the extraction of natural binders, such as starch, protein, lignin, and pectin from the plant cells, which favors the cohesion between the particles (DIAS et al., 2012).

Considering the above, the objective of this study was to evaluate the potential of briquettes production from the epicarp residues of the macauba fruit and to verify the influence of different temperatures and compaction pressures on the chemical, physical, and mechanical characteristics of the briquettes.

\section{MATERIALS AND METHODS}

In this study, the macauba epicarp was used, as it is one of the fruit processing residues for the extraction of oil for the production of biodiesel. For the production of the briquettes, the epicarp was reduced to particles with a hammer mill and classified in sieves with $2 \mathrm{~mm}$ mesh to characterize the briquette matrix, which has a diameter of $3 \mathrm{~cm}$ and a length of $15 \mathrm{~cm}$.

The determination of the higher calorific value of the particles was performed according to EN 14918 (DIN, 2010), using an Ika $300^{\circledR}$ adiabatic bomb calorimetric. For the immediate chemical composition, the standard NBR 8112 (ABNT, 1986) was followed, replacing the platinum crucible with a porcelain crucible and the temperature of $750^{\circ} \mathrm{C}$ for $600{ }^{\circ} \mathrm{C}$. For both analyses, the particles were classified in overlapping sieves of 40 mesh and 60 mesh, using the residue retained in the 60 mesh sieve.

The determination of the bulk density was adapted from DIN EN 15103 (2010), and the residues were packed in a container of $10 \times 10 \times 10 \mathrm{~cm}$ dimensions. By means of a precision analytical balance, the mass of the epicarp particles contained in the vessel volume was determined, and three replicates were performed. The bulk density was obtained by dividing the mass by the sample volume. 
For the determination of the structural chemical composition, the material was crushed using a Wiley type laboratory mill. The fraction that passed through the sieve with 40 mesh was used and was retained in the sieve with 60 mesh. The determination of the moisture content was performed according to TAPPI 264 om- 88 (TAPPI, 1996). The extractives contents were determined in duplicates, according to the TAPPI 204 om-88 standard (TAPPI, 1996), only replacing ethanol/benzene with ethanol/toluene. The insoluble lignin content was determined in duplicate by the Klason method, modified according to the procedure proposed by Gomide and Demuner (1986). Soluble lignin was determined by spectrometry according to Goldschimid (1971). The total lignin content was obtained by summing the values of soluble and insoluble lignin. The content of holocellulose was obtained by the sum of extractive, ash, and total lignin contents, subtracted from 100.

The briquettes were produced in a Lippel laboratory briquetting machine, model LB 32. Two temperatures $\left(90\right.$ and $\left.120^{\circ} \mathrm{C}\right)$ and three compaction pressures $(62,83$, and 103 bar) were implemented. The pressing time was 8 minutes, and the cooling time was 6 minutes. Seventeen grams of particles were used to produce each briquette.

In order to determine the mass loss (ML) occurred during the manufacture of the briquettes, the mass of residues used to produce each briquette was weighed in a precision scale. After the cooling time, the mass of the briquettes was also weighed. The weight difference between the mass of the waste and that of the briquettes was considered as the mass loss.

The determination of the higher calorific value of the briquettes followed the same methodology described for the epicarp particles. The apparent density was determined by weighing and subsequent immersion of the briquettes in mercury, obtaining the volume displaced according to the hydrostatic balance method described by Vital (1984). The energy density (ED) was calculated by the product between the higher calorific value and the apparent density of the briquettes.

A Contenco universal test machine, model I-3058-I, with a capacity of 10 tons was used to determine the bursting load of the briquettes. The briquettes were continuously and progressively compressed at a speed of $3.5 \mathrm{~mm} \cdot \mathrm{min}^{-1}$ until rupture. The reading of the maximum compressive strength (CS) was transferred to the software Pavtest.

For the evaluation of the experiment, a completely randomized design was used, arranged in a $3 \times 2$ factorial scheme with three compaction pressures $\left(62,83\right.$, and 103 bar) and two temperatures $\left(90{ }^{\circ} \mathrm{C}\right.$ and $\left.120^{\circ} \mathrm{C}\right)$ in eight repetitions each, totaling 48 sample units. For the evaluation of the treatments, the multiple linear regression model was fitted (Equation 1).

$$
Y_{i}=\beta_{0}+\beta_{1} X_{1 i}+\beta_{2} X_{2 i}+e_{i}
$$

In which: $Y_{i}$ : dependent variable obtained at observation $\mathrm{i} ; \beta_{0}, \beta_{1}, \beta_{2}$ : regression parameters; $X_{1 i}, X_{2 i}$ : independent variables in observation $\mathrm{i}$; and $\mathrm{e}_{\mathrm{i}}$ : error associated with observation $\mathrm{Y}_{\mathrm{i}}$.

The t-test was used to verify the significance of the regression parameters, tested at a level of $5 \%$ of probability. When one of the parameters was not significant, the adjustment of the simple linear regression model was performed, using only the independent variable whose parameter was significant by the t-test (Equation 2). To verify the quality of fit of the equation, the coefficient of determination $\left(\mathrm{R}^{2}\right)$ was used.

$$
Y_{i}=\beta_{0}+\beta_{1} X_{1 i}+e_{i}
$$

\section{RESULTS}

\section{Particle properties}

Table 1 shows the mean values of the chemical and physical properties of the macauba epicarp particles.

Table 1. Average values of chemical and physical properties of the particles of macauba epicarp.

Tabela 1. Valores médios das propriedades químicas e físicas das partículas do epicarpo da macaúba.

\begin{tabular}{ccc}
\hline Property & Average & Standard Deviation \\
\hline Higher calorific value $(\mathrm{HCV})\left[\mathrm{MJ} \mathrm{kg}^{-1}\right]$ & 23.25 & 0.06 \\
Volatile material content [\%] & 79.92 & 1.66 \\
Ash content [\%] & 4.79 & 0.26 \\
Fixed carbon content [\%] & 15.29 & 1.47 \\
Bulk Density [kg m$\left.{ }^{-3}\right]$ & 375.39 & 0.55 \\
Total extractives content $[\%]$ & 41.73 & 0.37
\end{tabular}

FLORESTA, Curitiba, PR, v. 48, n. 4, p. 563-572, out/dez. 2018

Teixeira. V. L. et.al.

ISSN eletrônico 1982-4688 


\begin{tabular}{ccc} 
Total lignin content [\%] & 35.26 & 0.54 \\
Holocellulose content [\%] & 23 & 0.17 \\
\hline
\end{tabular}

Properties of briquetes

In Table 2, the parameters of the adjusted linear models for the analysis of briquettes properties are presented.

Table 2. Parameters of linear models adjusted for mass loss, higher calorific value, apparent density, energy density, and compressive strength of briquettes according to temperature and compression pressure.

Tabela 2. Parâmetros dos modelos lineares ajustados para perda de massa, poder calorífico superior, densidade aparente, densidade energética e carga de ruptura dos briquetes em função da temperatura e pressão de compactação.

\begin{tabular}{|c|c|c|c|c|c|c|c|}
\hline \multirow{2}{*}{ Property } & \multicolumn{6}{|c|}{ Parameters of the adjusted models } & \multirow{2}{*}{$\mathbf{R}^{2}$} \\
\hline & $\beta_{0}$ & p-value & $\boldsymbol{\beta}_{\mathrm{T}}$ & p-value & $\beta_{\mathbf{P}}$ & p-value & \\
\hline Mass Loss (ML) & 0.4068 & $0.000^{*}$ & 0.011806 & $0.000 *$ & 0.003758 & $0.000 *$ & 0.87 \\
\hline $\begin{array}{c}\text { Higher Calorific value } \\
\text { (HCV) }\end{array}$ & 21.502 & $0.000^{*}$ & -0.00576 & $0.088 *$ & - & $0.813^{\mathrm{ns}}$ & 0.13 \\
\hline $\begin{array}{l}\text { Apparent density } \\
\text { (AD) }\end{array}$ & 665.8 & $0.000 *$ & 4.068 & $0.000 *$ & -0.440 & $0.043 *$ & 0.94 \\
\hline Energy Density (ED) & 14.608 & $0.000 *$ & 0.07896 & $0.000 *$ & -0.00998 & $0.063 *$ & 0.90 \\
\hline $\begin{array}{l}\text { Compressive Strength } \\
\text { (CS) }\end{array}$ & -146.83 & $0.000^{*}$ & 2.0056 & $0.000 *$ & - & $0.510^{\mathrm{ns}}$ & 0.97 \\
\hline
\end{tabular}

In which: $\mathrm{B}_{\mathrm{T}}$ : parameter assigned to the temperature factor; $\beta_{\mathrm{P}}$ : parameter assigned to the compression pressure factor; $*$ : significant at $5 \%$ by the t-test; ${ }^{\text {ns }}$ : not significant at $5 \%$ by the t-test; $\mathrm{R}^{2}$ : coefficient of determination.

For the properties higher calorific value and compressive strength, no significant effects of the compression pressure variable at $5 \%$ probability were verified by the t-test. Thus, a simple linear regression model was fitted, verifying linear trends between these properties and the temperature variable. For the other properties, multiple linear regression models were fitted, in which the results were presented by the respective response surfaces.

Figure 1 shows the estimated mass loss (ML) of the briquettes as a function of temperature and compaction pressure.

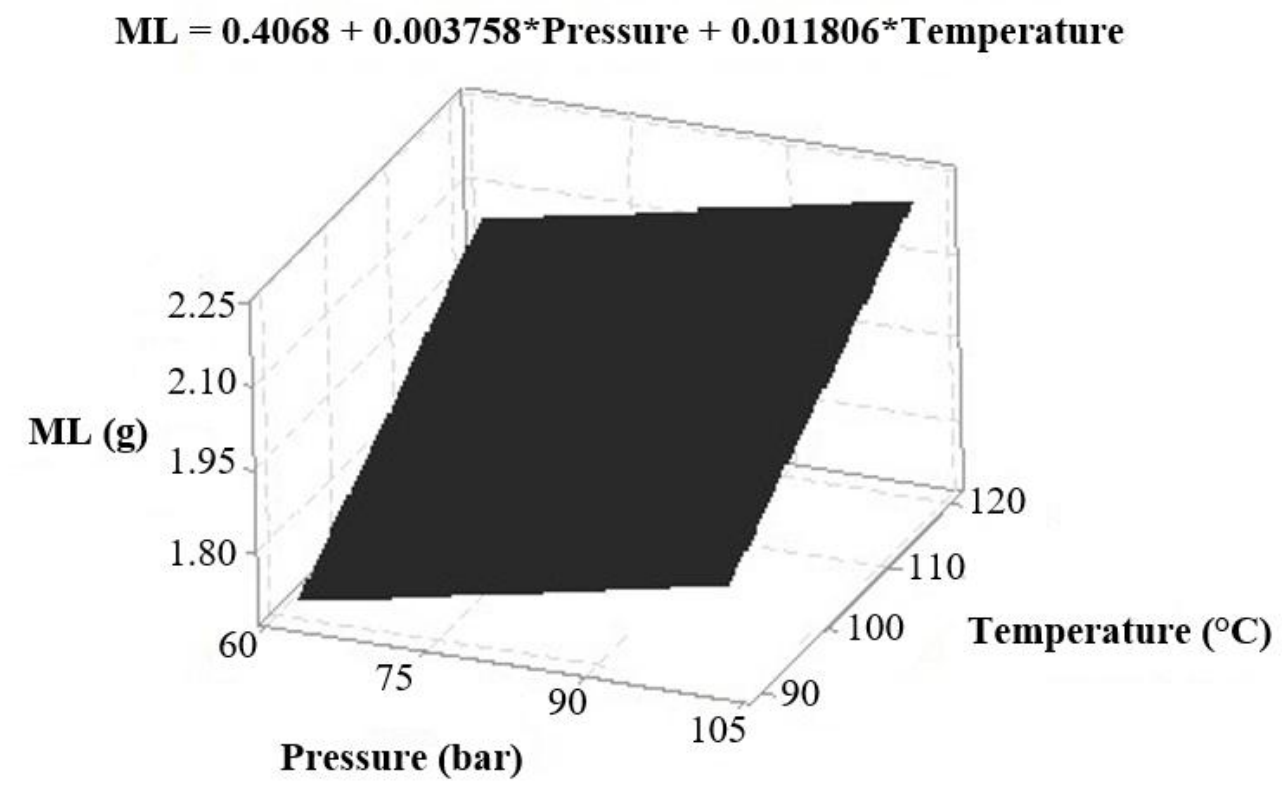

Figure 1. Mass loss of briquettes according to temperature and compaction pressure.

Figura 1. Perda de massa dos briquetes em função da temperatura e da pressão de compactação. 
Figures 2 and 3 present the estimated values of apparent density (AD) and energetic density (ED) of briquettes as a function of temperature and compression pressure, respectively.

$$
\mathrm{AD}=665.8-0.440 * \text { Pressure }+4.068 * \text { Temperature }
$$

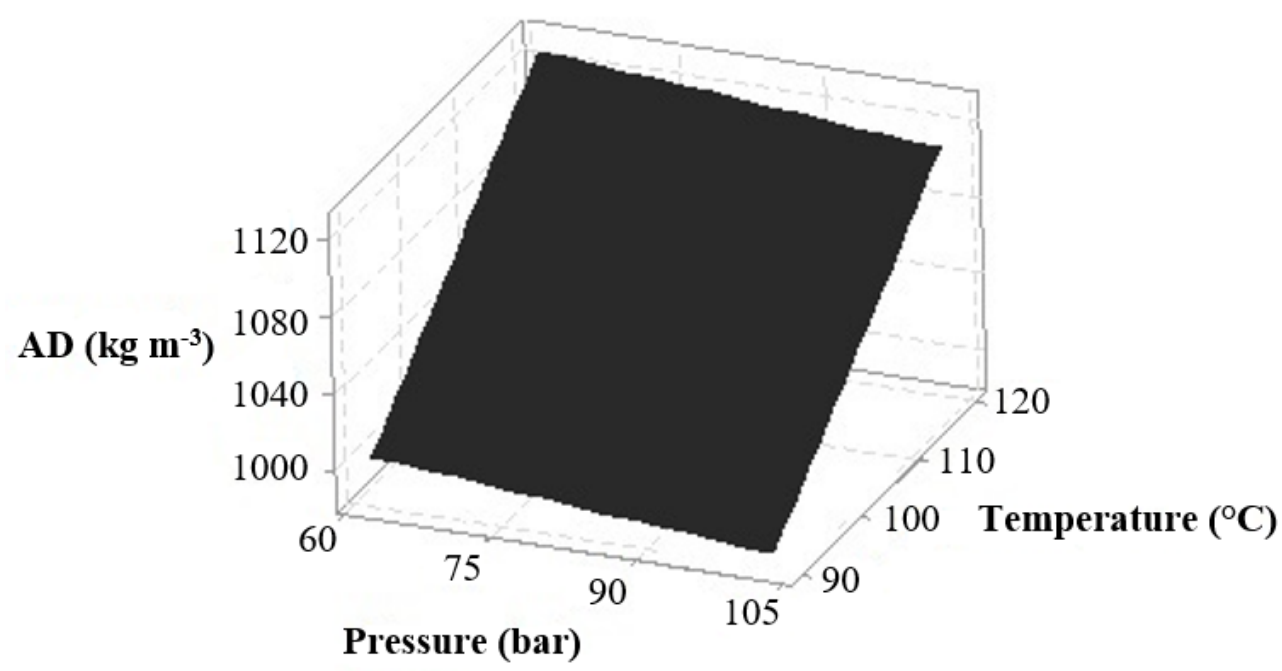

Figure 2. Apparent density of briquettes according to temperature and compaction pressure.

Figura 2. Densidade aparente dos briquetes em função da temperatura e pressão de compactação.

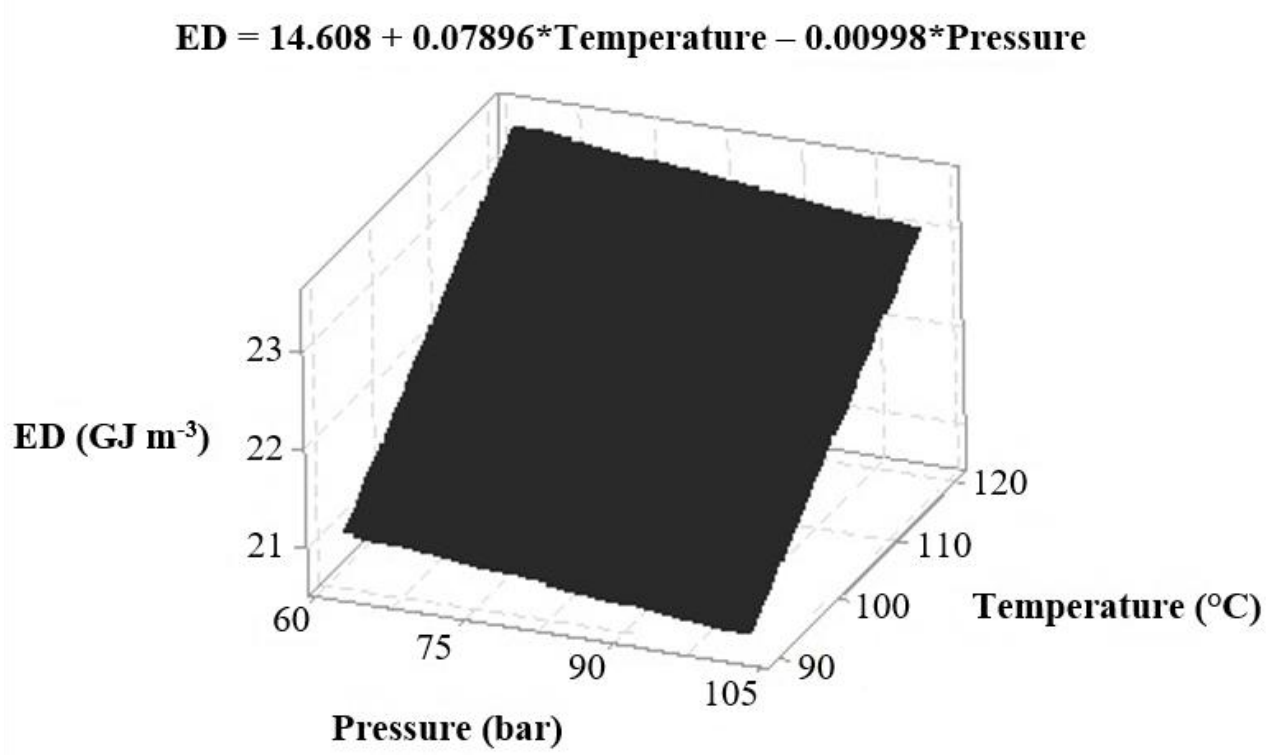

Figure 3. Energy density of briquettes according to temperature and compaction pressure.

Figura 3. Densidade energética dos briquetes em função da temperatura e pressão de compactação.

\section{DISCUSSION}

\section{Particle properties}

The volatiles content of the macauba epicarp resembled those reported for most of the vegetative biomasses (between 65 and 83\%) (EVARISTO et al., 2016). The bulk density was higher than that of Eucalyptus sawdust, which is the typical biomass used in the manufacture of briquettes and has a bulk density of approximately $224 \mathrm{~kg} \mathrm{~m}^{-3}$ (PROTÁSIO et al., 2011). According to Protásio et al. (2011), it is desirable to have lignocellulosic residues that present higher values of bulk density due to the direct influence on transport cost and energy density. 
According to Santos et al. (2011a), HCV is very important for the determination of the energy potential of a species and is influenced by the chemical composition of the biomass, mainly by the extractive and lignin contents. The epicarp presented a high calorific value, on average $23.25 \mathrm{MJ} \mathrm{kg}^{-1}$, which is superior to that of the Eucalyptus sawdust with a HCV of $19.18 \mathrm{MJ} \mathrm{kg}^{-1}$ (SILVA et al., 2015), pine sawdust with $18.28 \mathrm{MJ} \mathrm{kg}^{-1}$, angelim-red sawdust with $19.88 \mathrm{MJ} \mathrm{kg}^{-1}$ (FERNANDEZ et al., 2016), and paricá sawdust with $19.17 \mathrm{MJ} \mathrm{kg}^{-1}$ (FREITAS et al., 2016). These comparative values show its potential for bioenergy generation. The presence of oil in the particles, together with the high lignin content, contributed to the improved higher calorific value.

\section{Properties of briquettes}

Regression analysis indicated that the initial mass loss of the briquettes was affected by the increase in temperature and compaction pressure. In general, there was an increase in mass loss with the addition of these factors, probably due to water evaporation and volatilization of extractives during compaction. According to Furtado et al. (2010), the increase of the temperature and the increase of the pressure on biomass with higher content of volatile extractives causes the escape of these compounds to the medium, due to the reduction of the empty spaces inside the briquette. According to Rettore and Martins (1983), about $9.8 \%$ of the macauba epicarp is composed of oil. During the briquetting, the expulsion of the oil from the particles out of the briquetting matrix was verified, as can be observed in Figure 4. This fact also contributed to the difference between the mass of the particles and the mass of the briquettes.

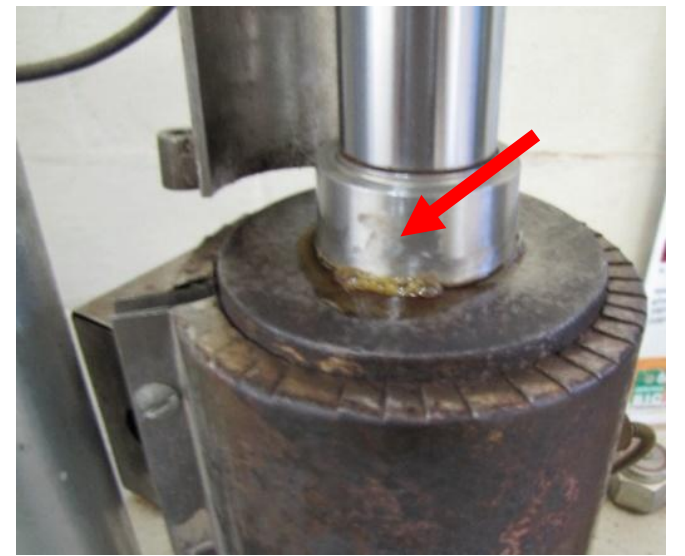

Figure 4. Particle oil (indicated by the red arrow) expelled from the briquetting machine matrix during compaction.

Figura 4. Óleo das partículas (indicado pela seta vermelha) expulso da matriz da briquetadeira durante a compactação.

Despite the low coefficient of determination, a significant effect was observed in the regression analysis for only the briquetting temperature in the $\mathrm{HCV}$ of the briquettes, while no effect was observed for the compression pressure. There was a linear trend, and the increase in temperature led to a slight reduction in the $\mathrm{HCV}$ of the briquettes. The low coefficient of determination indicates that it is necessary to add other factors to the regression model in order to better explain the variation in this property. Variables that may help explain this fact are the volatilization of the extractives and the particle oil loss during briquetting. According to Furtado et al. (2010), the temperature of the process and the increase in pressure exerts an opposite effect on the calorific value of the briquettes, causing its reduction as a function of the loss of the volatiles. According to Rettore and Martins (1983), the oil of the macauba epicarp has a high calorific value (39.23 MJ kg-1). Thus, the expulsion of the oil from the particles during the formation of the briquettes damages its HCV. It should be noted that the mean $\mathrm{HCV}$ of the particles was $23.25 \mathrm{MJ} \mathrm{kg}^{-1}$, while that of the briquettes was between 20 and $21 \mathrm{MJ} \mathrm{kg}^{-1}$. Therefore, there was a reduction of the initial energy potential.

The regression analysis indicated that the apparent density of the briquettes was affected by both factors. In Figure 2, it can be observed that the compression temperature and pressure had different effects on the response variable. As temperature increased, apparent density increased, possibly related to the higher plasticization of lignin at higher temperatures. This improves the bond between the particles and contributes to a lower number of empty spaces and, consequently, higher apparent density. The increase in pressure caused a slight reduction in $\mathrm{AD}$ of briquettes. This fact can be attributed to the greater mass loss presented by briquettes at higher pressures (Figure 1), since briquettes with same volume with lower values of mass in relation to the others, present lower AD. 
Evaluating briquettes of different biomasses, Silva et al. (2015) verified values of apparent density equal to $920 \mathrm{~kg} \mathrm{~m}^{-3}$ for Eucalyptus sawdust, $1000 \mathrm{~kg} \mathrm{~m}^{-3}$ for pine sawdust, $880 \mathrm{~kg} \mathrm{~m}^{-3}$ for sugarcane bagasse, and $1,110 \mathrm{~kg} \mathrm{~m}^{-3}$ for sugarcane straw, which are lower values than those presented in this study. Protásio et al. (2011) studied briquettes produced with Eucalyptus sawdust and residues of corn and coffee husk, which resulted in values between 1,060 and $1,240 \mathrm{~kg} \mathrm{~m}^{-3}$, and these results are very close to those observed in this study. According to Silva et al. (2015), a higher density of briquettes corresponds to a decrease in the volume of biomasses, evidencing the efficiency of these biofuels with respect to transportation and storage. Therefore, the high apparent density observed for macauba epicarp briquettes confirms the possibility of introducing this biofuel into the energy market.

Analyzing Figure 3, it is observed that the energy density increased with the increase in temperature and reduced with the increase in the compression pressure. This can be attributed to the directly proportional relationship between this property, the apparent density, and the higher calorific value. Since ED is the product between HCV and $\mathrm{AD}$, the values of these variables influence its result. In this study, because there was no significant effect of the compaction pressure and the temperature variation explained only a small part of the calorific power response, the apparent density had a great influence on the energy density values of the briquettes. This can be verified through the comparison of Figures 2 and 3, which shows that both have the same pattern of response.

When evaluating the research of Santin et al. (2017), who obtained average values of energy density for briquettes produced with 18.27, 19.40, and $18.52 \mathrm{GJ} \mathrm{m}^{-3}$ yerba mate branches, and Protasio et al. (2011), who verified an average value of $17.45 \mathrm{GJ} \mathrm{m}^{-3}$ for Eucalyptus sawdust briquettes, it is noticed that the briquettes produced in this study (average of $22.07 \mathrm{GJ} \mathrm{m}^{-3}$ ) present high energy density. This is very important in terms of commercialization of the product, since materials with low energy density represent an obstacle for its use, since they can increase transport costs (EVARISTO et al., 2016). Therefore, by concentrating more energy per unit volume, the macauba epicarp briquettes allow for a greater dilution of transport costs and allow for an extension of the commercialization radius.

The regression analysis showed that there was a significant effect of only the temperature on the briquette rupture load, presenting a linear increase trend. The higher cohesion and compaction of the particles, due to the higher plasticization of the lignin at a temperature of $120{ }^{\circ} \mathrm{C}$, promoted a greater compressive strength of briquettes with increasing temperature.

Freitas et al. (2016) studied the effects of pressure and compaction time on the properties of paricá wood (Schizolobium amazonicum) residues briquettes and found average values of rupture loading between 123 and $143 \mathrm{kgf}$. Santos et al. (2011b) evaluated the briquettes produced from the wood of native species and found the maximum value of the rupture load of $443.33 \mathrm{kgf}$ for the species Jurema-preta (Mimosa tenuiflora (Willd.) Poiret) and a minimum value of $143.33 \mathrm{kgf}$ for the Marmeleiro species (Croton sonderianus Müll.Arg.). These results were higher than the average values obtained in this study, that is, 33.70 and $93.80 \mathrm{kgf}$ for the temperatures of 90 and $120^{\circ} \mathrm{C}$, respectively. The lower compressive strength values found in this study can be explained by the high bulk density of the particles, which resulted in a lower compression ratio.

\section{CONCLUSIONS}

- The mass loss of the briquettes was accentuated with the increase in temperature and compression pressure.

- The elevation of the production temperature resulted in an increase in the apparent density and energetic density of the briquettes.

- The high calorific value, apparent density, and energy density of the briquettes produced from the macauba fruit epicarp demonstrate the potential of using this biomass to produce briquettes for the generation of thermal energy.

- Further studies related to the briquetting of macauba epicarp particles are recommended in order to increase the compressive strength of the briquettes.

\section{ACKNOWLEDGEMENTS}

To CNPq, Fapemig, and Capes for the support provided in the development of this research.

\section{REFERENCES}

ASSOCIAÇÃO BRASILEIRA DE NORMAS TÉCNICAS - ABNT. NBR 8112: Carvão vegetal: análise imediata. Rio de Janeiro, 1986. 8 p.

FLORESTA, Curitiba, PR, v. 48, n. 4, p. 563-572, out/dez. 2018

Teixeira. V. L et.al.

ISSN eletrônico 1982-4688 
AGÊNCIA NACIONAL DO PETRÓLEO, GÁS NATURAL E BIOCOMBUSTÍVEIS - ANP. Anuário estatístico brasileiro do petróleo, gás natural e biocombustíveis: 2016. Rio de Janeiro: 09/02/2017, p.265, 2016.

DEUTSCHES INSTITUT FUR NORMUNG - DIN. EN 14918: Determination of calorific value. Berlim, 2010. $63 \mathrm{p}$.

DEUTSCHES INSTITUT FUR NORMUNG - DIN. EN 15103: Solid biofuels - Determination of bulk density. Alemanha: CEN: 14 p. 2010.

DIAS, J. M. C. S.; SOUZA, D. T.; BRAGA, M.; ONOYAMA, M. M.; MIRANDA, C. H. B.; BARBOSA, P. F. D.; ROCHA, J. D. Produção de briquetes e péletes a partir de resíduos agrícolas, agroindustriais e florestais. Embrapa Agroenergia-Documentos (INFOTECA-E), Brasília, p. 130, 2012.

EMPRESA DE PESQUISA ENERGÉTICA - EPE. Balanço Energético Nacional: Relatório Síntese: Ano Base 2016. Rio de Janeiro, p.292, 2017.

EVARISTO, A. B.; MARTINO, D. C.; FERRAREZ, A. H.; DONATO, D. B.; CARNEIRO, A. C. O.; GROSSI, J. A. S. Energy potential of the macaw palm fruit residues and their use in charcoal production. Ciência Florestal, Santa Maria, v. 26, n. 2, p. 571-577, 2016.

FAVARO, S. P.; MIRANDA, C. H. B. Aproveitamento de espécies nativas e seus coprodutos no contexto de biorrefinaria. Embrapa Agroenergia, Documentos 14, p. 38, 2013.

FERNANDEZ, B.; GONÇALVES, B.; PEREIRA, A.; HANSTED, A.; PÁDUA, F.; DA RÓZ, A.; YAMAJI, F. Características mecânicas e energéticas de briquetes produzidos a partir de diferentes tipos de biomassa. Revista Virtual de Química, v. 9, n.1, p. 10, 2016.

FREITAS, A. J.; COSTA, A. C. S.; OLIVEIRA, A. C.; PEREIRA, B. L. C.; ROCHA, M. F. V.; CARNEIRO, A. D. C. O. Efeito da pressão e do tempo de compactação nas propriedades de briquetes de resíduos madeireiros de paricá. Nativa, Sinop, v. 4, n. 6, p. 380-385, 2016.

FURTADO, T. S.; VALIN, M.; BRAND, M. A.; BELLOTE, A. F. J. Variáveis do processo de briquetagem e qualidade de briquetes de biomassa florestal. Pesquisa Florestal Brasileira, Colombo, v. 30, n. 62, p. 101, 2010.

GOLDSCHIMID, O. Ultraviolet spectra. In: SARKANEN, K. V.; LUDWING, C. H. (Eds). Lignins: occurrence, formation, structure and reactions, New York, p. 241-266, 1971.

GOMIDE, J. L.; DEMUNER, B. J. Determinação do teor de lignina em material lenhoso: método Klason modificado. O papel, v. 47, n.8, p. 36-38, 1986.

LORENZI, G.; NEGRELLE, R. Acrocomia aculeata (Jacq.) Lodd. Ex Mart.: aspectos ecológicos. Visão Acadêmica, v. 7, n. 1, 2006.

MARTINS, M. P.; BENÍCIO, E. L.; DIAS JÚNIOR, A. F.; ALMEIDA, R. B.; CARVALHO, A. M.; YAMAJI, F. M. Produção e avaliação de briquetes de finos de carvão vegetal compactados com resíduo celulósico proveniente da indústria de papel e celulose. Revista Árvore, Viçosa, v. 40, p. 173-180, 2016.

MONTOYA, S. G.; MOTOIKE, S. Y.; KUKI, K. N.; COUTO, A. D. Fruit development, growth, and stored reserves in macauba palm (Acrocomia aculeata), an alternative bioenergy crop. Planta, v. 244, n. 4, p. 927-938, 2016.

PROTÁSIO, T. P.; ALVES, I. C. N.; TRUGILHO, P. F.; SILVA, V. O.; BALIZA, A. E. R. Compactação de biomassa vegetal visando à produção de biocombustíveis sólidos. Pesquisa Florestal Brasileira, v. 31, p. 273283,2011

RETTORE, R. P.; MARTINS, H. Produção de combustíveis líquidos a partir de óleos vegetais. Fundação Centro Tecnológico de Minas Gerais / CETEC. Belo Horizonte, p.241, 1983.

SANTIN, D.; SOBRINHO, G.; BREGUEZ, M.; CARNEIRO, A. D. C. O.; BENEDETTI, E. L.; BARROS, N. F. D. Phosphorus fertilization and harvest intervals influence energetic and physical properties of briquettes and large branches of mate. Revista Árvore, Viçosa, v. 41, n. 1, 2017. 
SANTOS, R. C.; CARNEIRO, A. C. O.; CASTRO, A. F. N. M.; CASTRO, R. V. O.; BIANCHE, J. J.; SOUZA, M. M. D.; CARDOSO, M. T. Correlações entre os parâmetros de qualidade da madeira e do carvão vegetal de clones de eucalipto. Scientia Forestalis, Piracicaba, v. 39, n. 90, p. 221-230, 2011 a.

SANTOS, R. C.; CARNEIRO, A. C. O.; CASTRO, R. V. O.; PIMENTA, A. S.; CASTRO, A. F. N. M.; MARINHO, I. V.; BOAS, M. A. V. Potencial de briquetagem de resíduos florestais da região do Seridó, no Rio Grande do Norte. Pesquisa Florestal Brasileira, Colombo, v. 31, n. 68, p. 285, 2011 b.

SILVA, D. A.; NAKASHIMA, G. T.; BARROS, J. L.; DA ROZ, A. L.; YAMAJI, F. M. Caracterização de biomassas para a briquetagem. Floresta, Curitiba, v. 45, n. 4, p. 713-722, 2015.

TECHNICAL ASSOCIATION OF THE PULP AND PAPER INDUSTRY - TAPPI. TAPPI test methods T 204 om-88: solvent extractives of wood and pulp. Atlanta: Tappi Technology Park. 1996. v.1.

TECHNICAL ASSOCIATION OF THE PULP AND PAPER INDUSTRY - TAPPI. TAPPI test methods T 264 om-88: preparation of wood for chemical analysis. Atlanta: Tappi Technology Park: 1996. 46 p.

VITAL, B. R. Métodos de determinação da densidade da madeira. SIF (Boletim Técnico, 1), p. 21, 1984. 
